Studia Anglica Posnaniensia 52(4), 2017

doi: 10.1515/stap-2017-0017

\title{
"GOLD ... WAS CERTAINLY VERY ATTRACTIVE; BUT HE DID NOT LIKE NEW SOUTH WALES AS A COUNTRY IN WHICH TO LIVE." THE REPRESENTATION OF AUSTRALIAN SOCIETY IN TROLLOPE'S JOHN CALDIGATE
}

\author{
AGNIESZKA SETECKA*
}

Faculty of English, Adam Mickiewicz University, Poznań

\begin{abstract}
Australia features in numerous Victorian novels either as a place of exile or a land of new opportunities, perhaps the most memorable image of the country having been presented in Charles Dickens's Great Expectations (1861). Anthony Trollope's writing, however, offers a much more extensive and complex presentation of Australian life as seen by a Victorian English gentleman. In his Australian fictions, including Harry Heathcote of Gangoil (1874), Catherine Carmichael (1878), and John Caldigate (1879), he presents Australia both as a land of new opportunities and as a place where social hierarchy as it is known in England is upturned and social boundaries either disregarded or drawn along different lines.

The present article is concerned with the ways in which Trollope's John Caldigate represents differences in the structure of English and Australian society, stressing the latter's lack of a clear class hierarchy characteristic of social organisation "back home". The society of Australia is presented as extremely plastic and mobile - both in terms of space and structure. Consequently, it can hardly be contained within a stiffly defined hierarchy, and it seems to defy the rules of social organisation that are accepted as natural and obvious in England. In Trollope's fiction success in Australia depends to a large extent on hard work, ability to withstand the hardships of life with no luxuries, and thrift, and thus on personal virtues, but the author nevertheless suggests that it is defined solely by economic capital at the cost of cultural capital, so significant in England.
\end{abstract}

Keywords: Anthony Trollope; John Caldigate; Australia; social class.

Agnieszka Setecka, Faculty of English, Adam Mickiewicz University, Al. Niepodległości 4, 61-874, Poznań, Poland, e-mail: saga@wa.amu.edu.pl 
Australia features in numerous Victorian novels either as a place of exile or a land of new opportunities, perhaps the most memorable image of the country having been presented in Charles Dickens's Great Expectations (1861). Anthony Trollope's writing, however, offers a much more extensive and complex presentation of Australian life as seen by a Victorian English gentleman. Apart from his popular travel book on Australia and New Zealand published in 1873 after he visited his son Frederic, who had settled in Australia as a sheep farmer, Trollope wrote fictions, including Harry Heathcote of Gangoil (1874), "Catherine Carmichael" (1878), and John Caldigate (1879), which are wholly or partially set in the Antipodes. Yet, postcolonial readings of Trollope's "Antipodean" fictions have tended to be neglected, most probably because Trollope has been "seen as the epitome of beefy Englishness", ${ }^{1}$ but also because his "colonial works are given short shrift by traditionally conservative Trollope scholars, and thus lack the visibility that would draw them to the eyes of critics involved in the postcolonial project", as Birns (1996: 7) points out in his article. Since the 1990s, Trollope's "Antipodean" fiction has been analysed in several other studies concerned with the representation of colonial life in literature, including Birns's own "Trollope and the Antipodes" (2011), Janet C. Myers's Antipodal England: Emigration and Portable Domesticity in the Victorian Imagination (2009), and Tamara Wagner's "Settling Back in at Home: Impostors and Imperial Panic in Victorian Narratives" (2011). All of these publications contribute significantly to bringing Trollope's colonial plots to the attention of readers and critics, offer insights into the complex interrelations between Victorian English and Australian cultures, and reveal ways in which major ideological assumptions about these cultures might be reconsidered.

The present article shares the conviction about the importance of literary representations of colonial experience in shaping Victorian ideology. It focuses on John Caldigate, "Trollope's most substantive Antipodean novel” (Birns 2011: 182), and the ways in which it represents differences in the structure of English and Australian society, stressing the latter's lack of a clear class hierarchy characteristic

In his Autobiography (1883) Anthony Trollope quotes Nathaniel Hawthorne, who indicates that Trollope's novels were "solid and substantial, written on the strength of beef and through the inspiration of ale, and just as real as if some giant had hewn a great lump out of the earth and put it under a glass case, with all its inhabitants going about their daily business, and not suspecting that they were being made a show of. And these books are just as English as a beef-steak. Have they ever been tried in America? It needs an English residence to make them thoroughly comprehensible; but still I should think that human nature would give them success anywhere" (Autobiography, 144). 
of social organisation "back home". ${ }^{2}$ Since John Caldigate, unlike Trollope's other Antipodean fictions, is set in both England and Australia, it is particularly relevant for the study of the ways Trollope constructed the distinctions between the two countries. The novel highlights aspects of Australian social life which the protagonist finds unfamiliar and exotic. The society of Australia that he has a chance to observe, first as a common gold-digger, and then as a businessman living off of the "large monthly dividends" he gets from one of his enterprises (John Caldigate, 123), is presented as extremely plastic and mobile - both in terms of space and structure. Consequently, it can hardly be contained within a stiffly defined hierarchy, and it seems to defy the rules of social organisation that are accepted as natural and obvious in England. As Durrey puts it, the novel "provocatively juxtapose[s] the apparent freedom of Australian life with that of England" (Durrey 2007: 171). Moreover, if success in the Australian gold fields is presented as depending to a large extent on hard work, thrift, and the ability to withstand the hardships of a life devoid of luxuries, and thus based on personal virtues, Trollope nevertheless suggests that success is defined solely by economic capital at the cost of cultural capital, so significant in England. Yet, although the societies of England and Australia are presented as substantially different, the novel, as it shifts between England and the Antipodes, forces the reader to recognize that even the apparently natural, clear-cut lines between the social classes in England are not only more porous and more problematic than it might seem at first glance, but that they are also arbitrary, especially in that economic, social, and cultural capital do not always correspond. If English society appears more ordered, being based on a hierarchy that stems from a long tradition, the novel exposes how much it may be ruled by arbitrary assumptions and prejudice.

Trollope's John Caldigate is the story of a rather careless young man, whose debts incurred while at Cambridge, passion for "slaughter[ing] rats and rabbits" (John Caldigate, 27), and other rather objectionable pastimes estrange him from his father. John decides to sell his inheritance and go to Australia as a common gold-digger. In the Antipodes, he proves to be more mature than his father gave him credit for, and thanks to his perseverance, common sense, thrift, sobriety, and a stroke of luck he becomes a rich man. He can now return to England in the full glory of his success and restore his place among the wealthy English squirearchy. The representation of John's journey to Australia and back to England offers the reader insight into the ways an English gentleman like John - or Trollope himself - perceived the differences and similarities between Australian and English society and social relations.

2 A similar observation on the contrast between the hierarchical structure of English society as opposed to the more "democratic" structure of Australian society was made by A. A. Philips in The Australian Tradition (1958) (Stewart 2009: 7). 
Victorian England was notorious for the complexity of its social divisions and rigid social hierarchy, which never depended solely on financial resources, but also on a variety of other, immaterial, criteria. In other words, class could hardly be defined by economic capital alone, but it also included social and cultural capital, as Bourdieu would describe them. In fact, when Trollope made an attempt at defining gentility, he put the questions of wealth and economic position aside, describing it instead as "the combination of soft words, soft manners, and soft hands with manly bearing, and high courage, and intellectual pursuits" (Trollope 1987 [1873]: I, 27). In other words, he described a gentleman's habitus, a set of dispositions that Bourdieu sees as literally "embodied" and determining the "way of standing, speaking walking and thereby feeling and thinking" (Bourdieu 1990 [1980]: 69-70).

If social position appeared to depend on immaterial criteria, it was nevertheless manifest through material signifiers, such as clothes, and through the manner of speech or outward demeanour. John Caldigate in Trollope's novel believed he was capable of reading such signifiers to establish other characters' position within the social hierarchy and to make very subtle social distinctions. His cultural competence thus made him aware of his own social superiority over his cousins, the Babingtons, who are described as "all of the earth earthy, without an idea among them" (Trollope 1987 [1873]: 3). Although in financial terms the Babingtons are John's equals, their vulgarity renders them inferior in moral terms to either him or Hester Bolton, who later in the novel becomes John's wife. The narrator signals their inferiority through their appearance, describing the Babington girls as "thick-legged, romping, cherry-cheeked damsels" (John Caldigate, 3), with the eldest Julia as "the thickest-ankled, and the cherrycheekedest of the lot" (John Caldigate, 8), features implying a lack of cultivation characteristic of country girls of inferior social position. Their rather unrefined nature becomes all the more evident when they are contrasted with Hester Bolton, who is constructed in the novel as the embodiment of middle-class feminine perfection, with her fair face and "large, grey, thoughtful eyes" (John Caldigate, 16), her virginal appearance underlined by her dress "as plain as a child's" (John Caldigate, 16), her restraint and generally silent disposition. And yet Hester's father was only a professional man, and therefore his position might appear inferior to that of a country squire like Mr Babington. While still in England, John is similarly capable of recognizing the social position of Richard Shand, later his companion on the journey to Australia, as being subtly lower than his own, and not just because of the Shands' strained financial situation. Richard Shand's family were "kind ... and good-humoured", but at the same time, they were rather "rough and coarse" (John Caldigate, 31), lacking the delicacy and tact that characterised the truly genteel. 
Just as John is capable of deciphering the subtle signifiers of class, other people can "read" his own position within the social hierarchy, so that he becomes an open book for competent readers. Although he decides to go to Australia as a simple gold-miner, and therefore not only dresses accordingly, but also buys a second-class ticket rather than travel with the more privileged first-class passengers, his disguise is immediately seen through. As the narrator remarks in the novel,

They [John Caldigate and Richard Shand] were both dressed according to the parts
they were acting, and which they intended to act, as second-class passengers and
future working miners. Any one knowing in such matters would have seen that they
were over-dressed; for the real miner, when he is away from his work, puts on his
best clothes, and endeavours to look as little rough as possible.

(John Caldigate, 40)

At this point in the story, their genteel background is evident for any person of even limited cultural competence, and their outfits prove a rather unsuccessful disguise. Although the very idea of gentility is notoriously problematic, John's fellow passengers recognize in him the qualities that constitute his social superiority despite both his financial situation and his occupation. As one of the ladies on board remarks: "Of course we all know that you are a gentleman", to which he answers: "I am much obliged to you; but I do not know any word that requires a definition so much as that. I am going to work hard to earn my bread; and I suppose these people are going to do the same" (John Caldigate, 62). Even when John works in the gold mines, his genteel upbringing can hardly be concealed, and it is evident in his gentlemanly bearing and the way he speaks. When he appears in Sydney to meet Mrs Smith, "[h]e was dressed as a miner might be dressed who was off work and out for a holiday; - clean, rough, and arranged with a studied intention to look as little like a gentleman as possible. The main figure and manner were so completely those of a gentleman that the disguise was not perfect; but yet he was rough" (John Caldigate, 112). What the novel suggests, then, is that class is not merely one's outward circumstances, but is inherent in a person's character, ingrained in one's very body and evident in one's manner.

If John's genteel background is presented as difficult to conceal or disguise, his attempt at disguising it might itself, however, be interpreted as a disruption of social boundaries, which appear to be relatively well-defined in England, but seem to be shaken on board the ship to Australia. Indeed, although the ship, the Goldfinder, is represented as a society in miniature, with the passengers divided into distinct social groups, the social divisions are not as clear as it originally seems. The narrator describes the situation on board the ship as reflecting the social structure on land: "How completely the society has formed itself into 
separate sets after the three or four first days! How thoroughly it is acknowledged that this is the aristocratic set, and that the plebeian! How determined are the aristocrats to admit no intrusion, and how anxious are the plebeians to intrude!" (John Caldigate, 38). The quotation implies that social divisions were very strict, copied as they were from English social life. It also indicates the existence of a conflict or tug of war on the border between the two classes, evident in the desire on the part of the second-class passengers to melt into the superior class, and thus suggests the possible blurring of the apparently clear-cut boundaries. In fact, the further the characters travel from England, the more incomprehensible and obscure the social distinctions; the closer they came to their destiny in Australia, the more questionable the boundaries between distinct classes became.

Mrs Euphemia Smith, whose acquaintance John makes on his way to Australia, and who later in the novel tries to falsely incriminate him for bigamy, embodies the upturning of class boundaries as they exist in England, since she challenges any attempt to place her in a clearly prescribed social group. When the reader first encounters her on board the Goldfinder, she is one of the secondclass passengers. However, much like John himself, even if for different reasons, she does not seem to belong there. Although she is "ill-dressed, untidy, almost unkempt on occasions" (John Caldigate, 44), which seems to signify her lower status, she evidently fails to identify with other second-class passengers:

\begin{abstract}
The woman [Euphemia Smith] herself had not only been able but had been foolish enough to show that in spite of her gown she considered herself superior to them all. When it was found that she was, in truth, handsome to look upon, - - that her words were soft and well chosen,- - that she could sit apart and read,- - and that she could trample upon Mrs. Crompton in her scorn,- - then, for a while, there were some who made little efforts to get into her good graces. She might even have made an ally of good-natured Mrs. Bones, the wife of the butcher who was going out with his large family to try his fortune at Melbourne. Mrs. Bones had been injured, after some ship fashion, by Mrs. Crompton, and would have made herself pleasant. But Mrs. Smith had despised them all, and had shown her contempt, and was now as deeply suspected by Mrs. Bones as by Mrs. Crompton or Mrs. Callander.
\end{abstract}

(John Caldigate, 58)

Mrs Smith's refusal to bond with either Mrs Callander from the first-class deck or the wife of the butcher seems to suggest that she stands alone, constituting a separate social category. Indeed, if Mrs Euphemia Smith appears to have very limited financial means, as her dress seems to imply, she nevertheless assumes the manners of the more cultivated classes and signals her status by her educated way of speaking and her ladylike manner. She even further stresses her distance from other second-class passengers by her aloofness. Her social status, however, is much more problematic than John's, the main reason being her sex. As a woman she is not expected to improve her position by earning money - quite the 
contrary, her involvement in business is presented in negative terms later in the novel - but is expected to meet very strict moral standards, which ideally should be reflected in her appearance and manner.

Significantly, if Mrs Smith is a morally doubtful character, she nevertheless proves to be particularly adept at managing signifiers of class or, rather, manipulating them to her own advantage. ${ }^{3}$ John, who can quite expertly identify the subtle class distinctions in England, is misled by her manner and appearance. At first he does not take heed of other passengers' more or less explicit warnings about Mrs Smith's unworthiness, and it is only much later that he finally realises that she is far from being respectable and, in fact, far from being a lady. Uncertain how he might end the relationship with her honourably when the ship reaches the shores of Australia, he continues it even after he realises the extent of his mistake. In fact, as ambiguous as her social standing is when John first encounters her on the Goldfinder, Mrs Smith's position becomes further problematized once she settles in Australia. She assumes the name of Mademoiselle Cettini and advertises herself as a singer and dancer, professions hardly considered appropriate for a respectable Victorian lady. As John Caldigate comments, "Dancing dances, singing songs, and acting tableaux; - and all under the name of Mademoiselle Cettini! Nothing could be worse" (John Caldigate, 109). Significantly, by making her an actress or performer, Trollope implies her doubtful morality, an impression evidently clear to Victorian readers: one contemporary reviewer called her "a woman who is already in possession of two names - one for shipboard use, the other placarded on the walls of Sydney in theatrical posters with a portrait encumbered with as few garments as may be" (Unsigned notice 1969 [1879]: 456). Mrs Smith's (or Mademoiselle Cettini's) profession further suggests her talent for deception and impersonation and, consequently, the idea that social class might be merely a matter of performance. ${ }^{4}$ As an adventuress and a social climber, a disreputable woman pretending to be a lady, Mrs Smith fits into the conventions of a sensation heroine. Indeed, as Hall indicates, although John Caldigate is "ultimately a Trollopian comedy, as are most of Trollope's more enduring works" (Hall 1993: xv), it nevertheless has "alliances to the sensation novel and to the

3 Elizabeth Langland argues that women, to a greater degree than men, were responsible for maintaining social status in the Victorian period, and were expected to be more adept at managing signifiers of class. She states: "Whereas men earned the money, women had the important task of managing those funds toward the acquisition of social and political status" (Langland 1995: 8) and indicates that "a mid-Victorian man depended on his wife to perform the ideological work of managing the class question and displaying the signs of middle-class status" (Langland 1995: 9).

4 The rather subversive idea of class being just a performance rather than being based on merit transpires in sensation fiction. Compare the analysis of Wilkie Collins's No Name in Setecka (2013: 174-179). 
detective story" (Hall 1993: xv) and "is rather more 'sensational' than the typical Trollope novel" (Hall 1993: xvi). Like many other sensation heroines, including Trollope's own Lady Eustace in The Eustace Diamonds (1872), ${ }^{5}$ Mrs Smith is a disruptive character who challenges the established social order. In this particular case, she "threatens the status of a respectably married English landowner by claiming the legal validity of their former relationship", which might be read in terms of the relation between England and the colonies, Mrs Smith embodying "the anarchic life of the colonies [which] threatens English patrilineal stability" (Taylor 2011: 91). It seems significant that Mrs Smith is so strongly associated with Australia, "that rough lawless wilderness" (John Caldigate, 353), a place where civilised laws seem to be suspended, as some of the characters tend to view the country.

In fact, the blurring of the boundaries between the social classes that John Caldigate witnesses on board the Goldfinder is just a preliminary stage to the complete upturning of social distinctions in Australia. John quickly learns that social classes as he knows them in England either disappear or are drawn along different lines, and this is true particularly on the gold-fields. Indeed, Trollope based the novel on his own experiences, gathered while writing a travel book on Australia, where he recorded his observations on a community of goldminers:

\begin{abstract}
Among such company it is impossible to recognise the social rank of each. There are what we call "gentlemen", and what we call "workmen". But they dress very much alike, work very much alike, and live very much alike. The ordinary miner who came perhaps from Cornwall or Northumberland, and whose father was a miner before him, gets a lift in the world, - as regards manners and habits as well as position. The "gentleman", even though in the matter of gold he be a lucky gentleman, gets a corresponding fall. He loses his gentility, his love of cleanliness, his ease of words, his grace of bearing, his preference for good company, and his social exigencies.
\end{abstract}

(John Caldigate, 26)

John Caldigate notes a similar process of levelling down among Australian miners, since, irrespective of their social background, they share the same hardships, the same food and the same lodgings: an extremely shabby "hotel" inhabited by a rather indiscriminate group of men who "were not uncivil. Australian miners never are so. But they were inquisitive, familiar, and with their half-drunken good-humour, almost repulsive" (John Caldigate, 80).

Even the local "aristocracy", as John soon realises, do not differ in any essential way from common miners, their greater wealth being the only feature that distinguishes them from other men. But neither are they morally superior to nor

5 Lady Eustace is another example of a sensation heroine in Trollope, sharing a number of characteristics with Mrs Smith; for an analysis of the ways Lady Eustace manipulates the signifiers of class see Setecka (2013: 155-167). 
differ in their way of life from other miners. Mr Crinkett, for example, the richest man in Nobble when John Caldigate and Richard Shand arrive there, does not use his newly acquired wealth to change his way of life, but rather, "he spent the greater part of his time away in other mining districts in which he had ventures. When thus absent, he would live as Jack Brien and his friends were living at Mrs. Henniker's and was supposed to enjoy the ease of his inn more thoroughly than he did the constraint of his grand establishment" (John Caldigate, 87). Mr Crinkett's house, which is one of the most important signifiers of class, expresses his nouveau riche mixture of wealth and lack of good taste. First of all, Mr Crinkett has his house built very near the mines, so that John, with his English notions of an ideal home, cannot help being surprised that "any man should have contemplated the building of such a mansion in a place so little attractive, with so many houses within view", especially given that

\begin{abstract}
The house and little attempted garden, together with the stables and appurtenances, may have occupied half an acre. All around it were those hideous signs of mining operations which make a country rich in metals look as though the devil had walked over it, dragging behind him an enormous rake. There was not a blade of grass to be seen. As far as the eye could reach there stood those ghost-like skeletons of trees in all spots where the soil had not been turned up; but on none of them was there a leaf left, or even a branch .... .
\end{abstract}

(John Caldigate, 85-86)

The house is implicitly contrasted with the one inhabited by John Caldigate's father, which ideally fulfils the ideological demand that it should constitute a private domain, as it is situated in the country, far away from the noise of the town, so as to become a true shelter from the hardships of life in the competitive environment of the city. Mr Crinkett might be "a swell" (John Caldigate, 86) by Australian standards, Trollope suggests, but his inability to use his money to manage his social or cultural capital through social signifiers rendered him socially inferior in the eyes of Victorian readers.

In his travel book on Australia, Trollope indicates that even in more "civilised" social groups in Australia, among the squatters, whose way of life was to a large extent modelled on English customs, the standards of genteel life were wanting. The squatters could best be described as corresponding with American ranchers, since they were "large scale graziers who leased huge tracts of land from the government to graze cattle and sheep ... By the mid-nineteenth century the squatters were considered by many to be the aristocracy of the Australian colonies, both because of their wealth and their connection to the land, likening their situation to the aristocratic and gentry, landowners of England. In fact, the term 'squattocracy' is often used to describe them" (Elliott 2011: 23). Although Australian squatters attempt to follow the genteel way of 
life and imitate English ways, they are never quite English in their inability to handle the most important signifiers of class. When squatters build their homes, for instance, the final result is that "the place has rarely all the finished comfort, the easy grace, coming from long habit, which belong to our own country seats at home. There is a roughness and a heaviness about it, a want of completion about the garden, of neatness about the paths, and of close-shorn trimness about the plots and lawns, which strikes the beholder at once, and declares that though the likeness be there, it exists with a difference" (Trollope 1987 [1873], I: 84). Significantly, whereas in Harry Heathcote of Gangoil and in "Catherine Carmichael" Trollope points to analogies between the English and Australian societies, so that even class conflicts in these texts "underscore in fact the superficiality, the ultimate exchangeability, of all the [social] conflicts" and "reveal that [social] formations are textually postulated and constructed" (Birns 1996: 11-12), John Caldigate seems to underscore the differences between Australia and England. In the society of goldminers, social distinctions disappear altogether, and consequently the society is presented as being constituted by unstructured groups of people who, independently of their origin and income, share roughness and uncouthness.

Mr Crinkett, with his wealth and uncouthness, therefore, belongs socially to a group that can hardly be recognised in England at all. When John is fresh in Australia and still looks at people around him through the prism of his English prejudices, he comments on Mr Crinkett's appearance, which reflects his ambiguous social standing: "He [Mr Crinkett] was dressed in black, with a chimney-pot on his head, - and certainly did not look like a miner, though he looked as little like a gentleman" (John Caldigate, 87). Neither a worker nor a gentleman, Mr Crinkett might be a perfect embodiment of the Australian lack of social hierarchy, while in England he seems to escape all classifications, consequently misleading any character who tries to read his class from his appearance. Indeed, when Mr Crinkett and his companions arrive in England to blackmail John Caldigate, their appearance evidently is a cause of anxiety because it does not send unambiguous signals to observers:

They were decently dressed,- dressed probably in such garments as gentlemen generally wear on winter mornings, - but any one (sic!) would know at a glance that they were not English gentlemen. And they were of an appearance unfamiliar to any one there but Caldigate himself, - clean, but rough, not quite at home in their clothes, which had probably been bought ready-made; with rough, ignoble faces,faces which you would suspect, but faces, nevertheless, which had in them something of courage. 
Wearing garments that are only "probably" like the clothing of gentlemen, $\mathrm{Mr}$ Crinkett and his friends are evidently not true gentlemen, a fact that a careful reader of appearance should notice after reading that the men do not quite feel comfortable in their garments, which are, in addition, "ready-made", so they probably neither fit perfectly nor constitute the men's habitual wear. $\mathrm{Mr}$ Crinkett's clothes, therefore, rather than help to define his social position, introduce confusion and uncertainty. Similarly, another Australian character, $\mathrm{Mr}$ Richard Bollum, who attempts to bribe John Caldigate in the novel, might appear "gentlemanly" to a servant, but would never be mistaken for a gentleman by a person more skilful in reading signifiers of class:

One day as he [John Caldigate] was entering the house by a side door, Darvell the gardener told him that there was a gentleman waiting to see him. ... Darvell, when asked whether the gentleman was a gentleman, expressed an affirmative opinion. He had been driven over from Cambridge in a hired gig, which was now standing in the yard, and was dressed, as Darvell expressed it, "quite accordingly and genteel." ... Caldigate, as he looked at the man, distrusted his gardener's judgment. The coat and hat and gloves, even the whiskers and head of hair, might have belonged to a gentleman; but not, as he thought, the mouth or the eyes or the hands. And when the man began to speak there was a mixture of assurance and intended complaisance, an effected familiarity and an attempt at ease, which made the master of the house quite sure that his guest was not all that Darvell had represented. The man soon told his story. His name was Bollum, Richard Bollum, and he had connections with Australia; - was largely concerned in Australian gold-mines.

(John Caldigate, 361)

It is interesting to see how class is in fact read by the English characters who themselves occupy different places in the social hierarchy: the servant takes into account financial status, which he judges on the basis of the fact that the stranger arrived in a gig and that his clothes were expensive. John, as a representative of a more cultivated class, realises that the clothes might indeed suit a gentleman, but the overall appearance does not. It is not clear what exactly he sees in "the mouth or the eyes or the hands" of the stranger, but it might be assumed that they are either not be delicate enough to belong to a man of the leisure class or that his manner is not like that of a true English gentleman. Class is thus presented as inscribed in the manner in which a person looks at his interlocutor, or the way he holds his hands, qualities which can hardly be simply "bought" like clothes. These are subtle signifiers of status that can be misread by a servant, but never by a true-born gentleman.

In contrast to Australian society, which is presented in the novel as devoid of a clear hierarchical structure, and to the Australian characters, who are never quite gentlemanly enough for English taste, and are always perceived as standing astride class divides, English society might appear well organised and 
ordered, with each character belonging to a properly prescribed social group. However, Trollope's novel makes readers realise both the factual porousness of the social divides in England, and the social prejudice, which might blind the society to the true worth of a character. Richard Shand is a good case in point, since from the very beginning of the novel his class position is not as unambiguous as it might seem, and after he arrives back in England after his sojourn in Australia and decides to present his evidence in the bigamy case, he has become too much of an Australian to be trusted by the members of the jury. Richard Shand is first presented in the novel as John Caldigate's "most intimate friend", which might imply their similar backgrounds, but also as a man of whom John would not wholly approve (John Caldigate, 29). Like John, Richard gets into debt as a student, but in contrast to John, he never bothers to pay the money he owes. Like John, he is Cambridge-educated, but he left the university "without taking a degree", though he "bears all these adversities with perfect equanimity" (John Caldigate, 29). He also seems to lack respect for conventions, as "[a]1l college discipline, all college authorities, all university traditions had been despised by Shand, who even in his dress had departed as far from recognised customs and fashions among the men as from the requisitions of the statutes and the milder requirements of the dignitaries of the day" (John Caldigate, 29). Later in the novel, when the two friends find themselves on board the Goldfinder, he finds much more enjoyment in the company of the second-class characters than John does, and in Australia he lacks the virtues of a true gentleman, proving too weak to resist his weakness for alcohol, so that instead of achieving any kind of success, he ends up as a "miserable Queensland shepherd" (John Caldigate, 128). If Dick's story can be read as a cautionary tale, presenting gambling and drinking as "two rocks on which gold-miners are apt to wreck their vessels" (John Caldigate, 126), it nevertheless also reveals the instability of social divisions, and exposes the idea that gentility is inborn and independent of external circumstances. When John reflects upon his friend's fate, he realises that they "had gone away equal"; yet, whereas John returns a rich man, "poor Dick was a wretched menial creature" (John Caldigate, 128). Even when Richard Shand finally returns to England a reformed man, having stopped drinking and achieved moderate success as a supervisor of workers in the sugar-cane fields, his class position remains ambiguous. In spite of his transformation and his Cambridge education, he "had not exactly the appearance of a well-to-do English gentleman" even though "he did not seem to be in want. The yellow trousers were of strong material, and in good order, made of that colour for colonial use, probably with the idea of expressing some contempt for the dingy hues which prevail among the legs of men at home" (John Caldigate, 473). However, English society evidently takes exception to the yellow trousers, as they are a piece of clothing an English 
gentleman would never wear. Julia Babington, for instance, exclaims "Did you ever see such trousers? ... I would not believe him on his oath" (John Caldigate, 495). While Julia is often the butt of Trollope's satire and is not a very significant figure in the novel, her opinion seems to be shared by more "serious" characters, including lawyers, who believe that Richard's "yellow trousers and the manners which accompanied them were not generally acceptable in merchants' offices and suchlike places" (John Caldigate, 612).

Australian society as presented in John Caldigate might be more democratic, but it is also unstructured and deprived of clearly-defined social boundaries, and thus not only constitutes a strong contrast to England's complex social structure, but also seems particularly inimical to the very idea of gentility as Trollope understands it. Indeed, as John Caldigate remarks, "[g]old ... was certainly very attractive; but he did not like New South Wales as a country in which to live" (John Caldigate, 123). This impression is enhanced by the fact that the key for reading the class code, which appears to John to be obvious and natural, can hardly be applied to Australian society, so that encounters with Australians leave English characters, including John himself, baffled by their inability to read the signifiers of class and to define other characters' place within the social structure. Moreover, as the novel takes the protagonist from England to Australia and back again, it makes readers realise that the English class structure is not as clear-cut as it might seem, and thus suggests the artificiality of these class divisions.

\section{REFERENCES}

\section{PRIMARY SOURCES}

Dickens, Charles. 1861. Great expectations. London: Chapman \& Hall.

Trollope, Anthony. 1987 [1873]. Australia, 2 vols. Gloucester: Alan Sutton.

Trollope, Anthony. 1990 [1872]. The Eustace diamonds. (Edited with and introduction by W. J. McCormack.) Oxford \& New York: Oxford University Press.

Trollope, Anthony. 1992 [1874]. Harry Heathcote of Gangoil. A tale of Australian bushlife. (Edited with an introduction by P. D. Edwards.) Oxford \& New York: Oxford University Press.

Trollope, Anthony. 1993 [1879]. John Caldigate. (Edited with an introduction by N. John Hall.) Oxford \& New York: Oxford University Press.

Trollope, Antony. 1995 [1878]. Catherine Carmichael: Or, three years running. In Anthony Trollope, Later short stories (Edited with an introduction and notes by John Sutherland), 492-514. Oxford \& New York: Oxford University Press.

Trollope, Anthony. 1999 [1883]. An autobiography. (Edited by Michael Sadler \& Frederick Page.) Oxford: Oxford University Press. 


\section{SECONDARY SOURCES}

Birns, Nicholas. 1996. The Empire turned upside down: The colonial fictions of Anthony Trollope. ARIEL: A Review of International English Literature 27(3). 7-23.

Birns, Nicholas. 2011. Trollope and the Antipodes. In Carolyn Dever \& Lisa Niles (eds.), The Cambridge companion to Anthony Trollope, 181-195. Cambridge: Cambridge University Press. DOI: 10.1017/CCOL9780521886369.015

Bourdieu, Pierre. 1990 [1980]. The logics of practice. (Translated by Richard Nice.) Stanford, CA: Stanford University Press.

Durrey, Jill Felicity. 2007. Modern issues: Anthony Trollope and Australia. Antipodes 21(2). 170 176.

Elliott, Dorice Williams. 2011. Unsettled status in Australian settler novels. In Tamara S. Wagner (ed.), Victorian settler narratives: Emigrants, cosmopolitans and returnees in nineteenth-century literature, 23-40. London \& New York: Routledge.

Hall, N. John. 1993. Introduction. In Anthony Trollope 1993 [1879]. John Caldigate, vii-xix. Oxford \& New York: Oxford University Press.

Langland, Elizabeth. 1995. Nobody's angels: Middle-class women and domestic ideology in Victorian culture. Ithaca, NY: Cornell University Press.

Myers, Janet C. 2009. Antipodal England: Emigration and portable domesticity in the Victorian imagination. New York, NY: State University of New York Press.

Phillips, Arthur A. 1958. The Australian tradition: Studies in colonial culture. Melbourne: Cheshire.

Pierce, Peter (ed.). 2009. The Cambridge history of Australian literature. Cambridge: Cambridge University Press. DOI: 10.1017/CHOL9780521881654

Stewart, Ken. 2009. Britain's Australia. In Peter Pierce (ed.), The Cambridge history of Australian literature, 7-33. Cambridge: Cambridge University Press. DOI: 10.1017/CHOL9780521881654.003

Taylor, Jenny Bourne. 2011. Trollope and the sensation novel. In Carolyn Dever \& Lisa Niles (eds.), The Cambridge companion to Anthony Trollope, 85-98. Cambridge: Cambridge University Press. DOI: 10.1017/CCOL9780521886369.008

Setecka, Agnieszka. 2013. Vanishing realities. Social significance of material culture in Victorian novelistic discourse. Poznań: Wydawnictwo Naukowe UAM.

Unsigned notice 1969 [1879]. In Donald Smalley (ed.), Anthony Trollope: The critical heritage, 456. London \& New York: Routledge.

Wagner, Tamara S. 2011. Settling back in at home: Impostors and imperial panic in Victorian narratives. In Tamara S. Wagner (ed.), Victorian settler narratives: Emigrants, cosmopolitans and returnees in nineteenth-century literature, 111-128. London \& New York: Routledge. 